\title{
Furoshiki: An Art of Cloth Wrapping as an Alternative to Replace Bag (Goods)
}

\author{
N S Sasanti ${ }^{1}$ and A H Milanguni ${ }^{2}$ \\ ${ }^{1}$ Universitas Negeri Surabaya, Indonesia \\ ${ }^{2}$ Universitas Gadjah Mada, Indonesia \\ nisesamudra@unesa.ac.id
}

\begin{abstract}
Food wrappers that are usually used to wrap food, in fact, are very dangerous for health. All types of plastic are made from crude oil with a mixture of various toxic chemicals. There are several solutions to overcome plastic waste. Among all the solutions, there is one of the easiest solutions for us to do together, which is by promoting environmentally friendly programs. One example of this program is by adopting a tradition from Japan called furoshiki. This tradition uses cloth as a wrapper. In fact, in Indonesia, especially in Central Java, the cloth used as a wrapper has existed a long time ago. The mothers of batik traders or other material traders also use cloth as wrappers. Even this is still seen in Yogyakarta. Therefore, it would be wise if we, as the next generation, reuse cloth as wrappers for goods to avoid all risks that can harm our bodies and people around us. The most important thing from furoshiki is the concept of repeated use, means that furoshiki is not only used for once but used repeatedly. Using furoshiki means reducing the use of new material for packaging so that it can reduce excessive packaging use.
\end{abstract}

Keywords: goods; furoshiki; cloth wrapping

\section{INTRODUCTION}

In the present day, plastic has a big contribution to daily life. This fact makes users of plastic wrappers or plastic containers in society higher. It starts with food wrapper, plastic bags, food, and drink containers and so forth. Food wrapper that is usually used to protect our food is very dangerous for health. According to a journal, it stated that the use of plastic that is not in line with rules and regulations would occur various health disturbances because it causes to trigger cancer and damage on human body's tissues (carcinogenic). What is more, plastics are commonly difficult to be degraded (decomposed) by microorganism [1].

There are some solutions that can be done to overcome plastic waste. Above all the solutions, there is one that is easily carried out together. That solution is that by not using any plastic bags (kresek), but by promoting an eco-friendly program for the nature that has been concerned day by day. Is not it easy? If we do not use plastic bags, so there will be no plastic waste. The ecofriendly program is one of the solutions that can be carried out to overcome plastic waste, such by adopting a Japanese tradition existed a long time ago, which is by utilizing wrapper cloth known by the name Furoshiki.

In Japan, Furoshiki is a cloth used to wrap various goods. In fact, this culture is found not only in Japan. Indonesian people, actually use cloth as goods wrappers. It can be seen in traditional markets. They bring their selling goods and wrap them by using cloth. The cloth they 
use is eco-friendly because it can be reused many times. Furthermore, the use of cloth as goods wrapper can be used as one of the ways to decrease the use of plastics also to invite the young generation to decrease the use of plastic packaging.

\section{METHOD}

This research belongs to qualitative descriptive research. Qualitative descriptive research is research that uses a case study method or approach. Case study data can be obtained from all parties concerned, in other words in this study, data are collected from various sources [2]. This research aims to provide knowledge to society and to support the government in reducing plastic use.

Data collection techniques are carried out by doing literature reviews and documentation. The literature review is carried out by describing the consequences of using plastic and describing the meaning and techniques of using furoshiki. After explaining the definition of furoshiki, a law introduced that supports the reduction of plastic use. Furthermore, in this study, a way is provided to familiarize society with the use of furoshiki, which is by teaching furoshiki folding skills.

\section{RESULT AND DISCUSSION}

The following are the results and discussion in this study. The explanation begins by giving an introduction to the dangers of using plastic for the environment, using furoshiki, and the role of the government in reducing plastic use. Furthermore, the steps are given for socialization activities or training on the use of furoshiki.

\subsection{Furoshiki}

\subsubsection{Definition of Furoshiki}

The definition of Furoshiki is [3]:

風呂敷は、布を折りたたんだもので、物品などを包んで持ち運び

やくするために用いられるものです。人に贈り物っていくとき、風呂敷に包ん

でいき。贈り物を受け取る人に手渡す直前に、風呂敷を解くのが普通です。

"Furoshiki is a cloth wrapper or cloth used to wrap a good so that the goods can be easily carried everywhere. Furoshiki commonly used at the time to give someone a gift, then the gift is wrapped by furoshiki and open it before giving the gift to that gift recipient [3].

Meanwhile, according to Japanese-Indonesia dictionary, furoshiki (風呂敷) is a cloth wrapper. From the mix of existing characters, so the kanji furo (風呂) can be translated as bathe. Meanwhile, Shiki (敷) has the meaning as unfolding (cloth) as a cover [4].

Furoshiki (風呂敷) is an art of wrapping food or goods done traditionally. The art of furoshiki was introduced by Japanese people since B.C. Before the word furoshiki became famous among Japanese people, the people knew the art of furoshiki by the name hirazutsumi (平包) which means folded wrapper [5]. 


\subsubsection{The History of Furoshiki}

Furoshiki started in the Nara era (710-794). However, no one ever named the wrapper cloth by the name furoshiki, and it had meaning as wrapping cloth, which is a simple cloth that later cut equilateral, then sewed. As it developed, in the Nara era, exactly in the year 756, the cloth became a cloth wrapper. For instance, in that year, it was built a building named shosoin (正倉院) to store art goods and Emperor Shomu's inheritance near Todaiji (東大寺) in Nara [6].

Later in the Nara era, Japanese people already had thought that if giving something to someone, one should wrap it, so that "cloth wrapper" or Tsutsumi started to get utilized as a tool to wrap any goods. In the Nara era, it was also common a cloth wrapper which named as Hokeifuhaku.

"The prototype of the furoshiki, the most common cloth used in Japan for gift wrapping, is the Hokei-fuhaku or square fabric like that found in the shosoin treasure house. Back to the Nara period, the Hokei-fuhaku is said to have been used for wrapping items such as the stoles of a Buddhist priest and the costumes of minstrels. At the time, wrapping clothes were known as Tsutsumi(wrapping) or hiratsutsumi (flat wrapping) [6]."

Japanese people use furoshiki in public baths as cloth for wrapping clothes and toiletries. The use of furoshiki as a wrapping cloth is gradually used also at weddings, as a wedding gift wrapper. Fabric motives used in the use of a wedding gift wrapper, it was chosen motives that bring blessings and happiness.

\subsubsection{Motives and Use of Furoshiki}

Furoshiki has a rectangular shape. The size of furoshiki can be made as desired by the user because there is no patent rule about furoshiki size. The size can be as big as bed sheet if it is used to wrap a motorcycle. There are many kinds of furoshiki motives, but there are several motives that are the users' favorite, including the crane's motif, fan motif, pine tree motif, and wave motif. Those motives are believed to bring blessings and happiness. Also, materials for making furoshiki consist of various kinds of materials, such as cotton, nylon, rayon, and silk.

Furoshiki has many uses because it can be used to pack various kinds of goods. It can be used for packaging, so that it can be used for carrying, storing items, as a cloth for wrapping food supplies, it can also be used as a floor mat or room decoration, as well as wrapping cloth for clothes and toiletries. Furthermore, furoshiki is also used for weddings as a gift wrapper in the wedding procession and as a bag or gift wrapper or a gift. Besides that, it can be used as a food and cake wrapper, bag, a food box wrapper, a bottle wrapper, and a table mat. Below are some examples of furoshiki shapes that can be formed according to the goods:

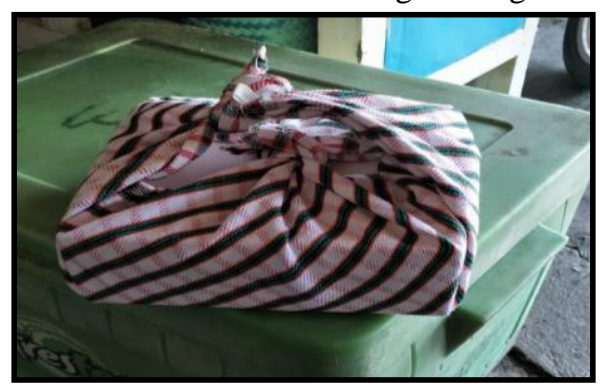

Figure 1. Example of the use of furoshiki in daily life 


\subsubsection{Basic Techniques in Using Furoshiki}

Furoshiki has several forms and they have their own functions. This means that furoshiki can be used to wrap goods in accordance with the items that will be carried. There is a technique used in wrapping furoshiki, the most basic and commonly used is the otsukai tsutsumi which is applied to square objects.

Here are the types and functions of furoshiki wrapping techniques.

1. Otsukai-tsutsumi and Hira-zutsumi are the most basic packages commonly used to carry thin (flat) objects. This technique is actually a non-knot wrapper.

2. Bin-tsutsumi is a package commonly used to carry bottles. There are two bin-tsutsumi styles, one for carrying one bottle and for carrying two easy bottles.

4. Entou-tsutsumi is a wrap technique to carry long-shaped objects.

5. Hikkake-tsutsumi is a technique of wrapping objects that have a rectangular shape.

6. Yotsu-tsutsumi is a safer technique than otsukai-tsutsumi with 2-4 knots. This technique is a better technique for carrying box-shaped or cube-shaped goods.

7. Katakake fukuro (technique of wrapping furoshiki that can be carried on the shoulder) [3],[5].

Making furoshiki by size of $50 \mathrm{~cm} \times 50 \mathrm{~cm}$ is perfect for bento/lunch or other small things. If someone wants to wrap a bottle of wine or make furoshiki that functions as a bag one should cut the cloth size larger. The most common sizes are $45 \mathrm{~cm}$ (17.7 inches) and $68-72 \mathrm{~cm} \mathrm{(26.7}$ - 28.3 inches) [7].

\subsection{Government Role for the Society}

The government is expected to play an active role in promoting the utilization of furoshiki, so that furoshiki will be known to society. The thing that can be executed by the government is to providing knowledge and understanding and further providing a discourse on the provision of training and how to utilize furoshiki. In this activity, the government must direct, to regulate, and to control activities through various policies, laws and direct actions on the field. The main objective is to improve environmental awareness. Besides being able to create employment opportunities, the provision of furoshiki utilization is expected to be able to increase the growth of the family economy. All activities are carried out to create a purpose for achieving government goals.

As evidence of the government's active role in the use of furoshiki, the Indonesian government has actually issued regulations written in Law No. 4 of 1982 concerning Basic Provisions for Life Management [8]. The law reads Chapter III Rights, Obligations and Authorities, Article 5 (1) Every person has the right to have a good and healthy environment. (2) Every person is obliged to maintain the environment and to prevent as well as to overcome its damage and pollution. Article 6 (1) Every person has the right and obligation to participate in environmental management. (2) The participation as referred to in paragraph (1), this article is regulated by legislation. Article 7 (1) Every person who runs a business sector must maintain a harmonious and balanced environment to support sustainable development. (2) The obligation as referred to in paragraph (1), this article is included in every permit issued by the authorized institute. (3) Provisions regarding the obligations referred to in paragraph (1) and paragraph (2), this article shall be appointed by legislation. Every person has the right to have a good environment, is obliged to maintain the environment and prevents and overcomes its damage and pollution [8]. By making these regulations, the utilization of furoshiki can be used as a way to support and to implement the law that has been issued. 


\subsection{Socializing Furoshiki}

Socializing furoshiki (the skill of wrapping things with Japanese-style fabric) is not easy, because people are not used to it and may not even know what furoshiki is, although these skills already exist and are used by Indonesians, especially Javanese, particularly in Central Java or more specifically in the Special Region of Yogyakarta (Daerah Istimewa Yogyakarta or DIY). The cloth wrapping luggage in DIY has been utilized mainly by the merchant mothers who commutes to the market every day where she works to pack her commodities. In Indonesia, particularly in DIY, the wrapper is not given a special name but is used to wrap goods. However, as time goes by, the wrapping cloth gradually disappeared, and even only certain people still used it, especially the sellers in traditional markets.

\subsection{Furoshiki Folding Skill Training}

Introducing furoshiki is not easy, because people are used to using plastic bags. Therefore, the government is expected to play an active role in promoting it more actively. There are several ways for furoshiki to be accepted by the community, namely by providing free samples of goods on a limited scale, accompanied by providing training. Training is carried out by freeing up fees so that they can enjoy and feel the benefits of furoshiki. With the results of the work they have obtained, the training participants will convey to the community around them. Therefore, slowly but sure, furoshiki will be accepted in society.

Furoshiki needs to be socialized first in the sub-district. Then, it will be socialized later in the urban village, the hamlet (RW), and finally the neighborhood (RT). In the sub-district sector, the office holders can assign their staff to introduce furoshiki through schools, such as elementary, junior high school, high school, and kindergarten and early childhood school under their authority. Training is directly handled by a leader or appointed by the institute that has been given responsibility. The training at school will be given first to the teachers. Furthermore, the results of the training by the teachers are given to students in their respective schools. In the scope of the community, the introduction of furoshiki is given to the mothers of the dasa wisma, as responsible for training are those who have competence in the field. This training is intended for mothers and children, to minimize the use of plastic bags in food wrapping. In addition, to allow the mothers to change plastic to cloth to wrap children's supplies, this socialization is also more effective if it is introduced early to the next generation as well as to kindergarten and elementary school students.

\section{CONCLUSION}

Organizing training in the utilization of furoshiki, except for managing the environment, also aims to improve HR capabilities and expertise. After increasing the capabilities and expertise of $\mathrm{HR}$, this training is also able to support environmentally friendly programs, which had been launched by the government. Therefore, this program needs to be escorted, so that government policies can run by the program. The government is expected willingly to give awards to engineers or companies that are willing to release environmentally friendly products, which in this case, to replace plastic with the use of furoshiki. The awarding of the award is also an effective promotion for the government, so that producer will compete in reducing the use of plastics. So, the government program is by Law No.4 of 1982 so as it has a positive impact on society. If the product is available, the community will start using these environmentally 
friendly products. It is also hoped that sanctions will be imposed on offenders who do not use environmentally friendly materials, of course, it is indiscriminately, so that a generation that will love environmentally friendly products and environmental preservation will be created.

\section{REFERENCES}

[1] N. Karuniastuti, "Bahaya Plastik,” Forum Tenologi, vol. 03, no. 1, pp. 6-14, 2017.

[2] H. Nawawi, Metode Penelitian Ilmu-Ilmu Sosial. Yogyakarta: Gadjah Mada Press, 2003.

[3] F. Nurhinaya, D. K. Izmayanti, and O. Amril, “Furoshiki Dewasa Ini,” 感染症誌, vol. 91, pp. 399-404, 2017.

[4] K. Matsuura, Kamus Jepang-Indonesia. Kyoto: Kyoto Sangyo University Press, 1994.

[5] J. R. Ketaren, "Fungsi dan Manfaat Furoshiki: Furoshiki No Kouka To Kinou," Universitas Sumatera Utara, 2014.

[6] C. Morita, Gift Wrapping with Textile. London: Kondansha America, Inc, 2015.

[7] N. Kira, "Furoshiki Kain Pembungkus Tradisional Jepang," Artforia, 2017. [Online]. Available: https://www.artforia.com/furoshiki-kain-pembungkus-tradisional-jepang/.

[8] Presiden Republik Indonesia, "Undang-Undang Republik Indonesia Nomor 4 Tahun 1982," 1982. 